\title{
Uji Laboratorium Efektivitas Biosurfaktan "U-Champ" dalam Bioremediasi Oil Spill
}

\begin{abstract}
ABSTRAK
Tumpahan minyak bumi (Oil Spills) merupakan salah satu dampak lingkungan yang serius dari kegiatan industri migas (petroleum industries). Salah satu upaya dalam mengelola tumpahan minyak tersebut yaitu dengan melakukan bioremediasi menggunakan biosurfaktan. Kecamatan Cepu, Kabupaten Blora, Jawa Tengah telah menjadi tambang minyak bumi tradisional sejak tahun 1893. Dari tambang inilah banyak terjadi tumpahan minyak dari proses produksi. Penelitian bertujuan untuk mengujikan keefektifan biosurfaktan pada tanah tercemar Cepu dalam penurunan Total Petroleum Hydrocarbon $(T P H), \mathrm{pH}$, dan logam berat. Metode yang dilakukan dengan cara mengaduk tanah tercemar dengan larutan biosurfaktan "U-Champ". Berdasarkan dari hasil pengujian, terjadi penurunan TPH dari 13,49\% menjadi 9,39\% dan penurunan tingkat keasaman dari 9,21 (basa) menjadi 7,16 (netral). Beberapa logam berat pada tanah mengalami penurunan namun beberapa pula justru mengalami peningkatan, seperti Ba dari kadar 249,6 ppm menjadi 302,9 ppm dan Se dari kadar 1,5 ppm menjadi 2,6 ppm. Sebaiknya dilakukan penelitian lebih lanjut dengan penambahan variabel pengujian seperti konsentrasi biosurfaktan yang berbeda, sehingga dapat dilakukan pengujian yang lebih efisien untuk sampel tanah tersebut.
\end{abstract}

Kata kunci: biosurfaktan; bioremediasi; oil spills.

\begin{abstract}
Oil spills are one of the serious environmental impacts in oil and gas industry activities. One effort to manage the oil spill is to conduct bioremediation using bio-surfactants. Cepu Subdistrict, Blora Regency, Central Java has been a traditional oil mine since 1893. From this activity many oil production spills occur.

Research carried out is testing the effectiveness of bio-surfactants in Cepu polluted soils in decreasing Total Petroleum Hydrocarbon (TPH), pH, and heavy metals. The method is carried out by stirring contaminated soil with a "U-Champ" bio-surfactant solution.

Based on the test results, TPH decreased from $13.49 \%$ to $9.39 \%$ and decreased acidity from 9.21 (bases) to 7.16 (neutral). Some heavy metals in the soil have decreased but some have also increased, such as Ba from 249.6 ppm to 302.9 ppm and Se from 1.5 ppm to 2.6 ppm. Further research should be carried out by adding test variables such as different bio-surfactant concentrations, so that more efficient testing can be done for the soil sample.
\end{abstract}

Key words: Bio-surfactans; bioremediation; oil spills.

\section{PENDAHULUAN}

Minyak bumi merupakan salah satu sumber energi yang sangat penting dan bahan mentah untuk industri kimia. Ketergantungan pada minyak bumi dan kegunaan dari minyak bumi sebagai bahan bakar tersebut telah berpengaruh kepada pembangunan ekonomi. Meskipun industri perminyakan sangat menguntungkan masyarakat, namun industri ini juga menghasilkan limbah berbahaya yang banyak. Terlebih lagi tumpahan minyak pada proses eksplorasi, transportasi, dan pengilangan telah menyebabkan masalah lingkungan yang serius (Silva et al., 2014).

Sebenarnya Lingkungan itu sendiri memiliki kemampuan untuk mendegradasi senyawa-senyawa pencemar yang masuk ke dalamnya, namun sering kali beban pencemaran di lingkungan lebih besar dibandingkan dengan kecepatan proses degradasi zat pencemar tersebut secara alami. Akibatnya zat pencemar akan terakumulasi sehingga dibutuhkan campur tangan manusia dengan teknologi yang ada untuk mengatasi pencemaran tersebut. Bioremediasi menjadi salah satu pilihan teknologi untuk mengembalikan kondisi tanah yang terkontaminasi hidrokarbon minyak 
bumi. Dari segi biaya dan kelestarian lingkungan, bioremediasi lebih murah dan berwawasan lingkungan dibandingkan dengan metode pemulihan lingkungan lainnya (Kusumawati et al., 2015).

Biosurfaktan merupakan produk bioteknologi yang penting dengan fungsi yang luas pada banyak industri. Beberapa sifat menarik dari biosurfaktan antara lain: merubah permukaan aktif seperti menurunkan IFT (interface tension); melembabkan dan merasuk dalam media; menyebar; hydrophobic dan hydrophilic; katalisator perkembangan mikrobia; menyerap logam; dan anti mikrobia. Beberapa keunggulan biosurfaktan dibandingkan dengan produk kimia sintesis lainnya yaitu: biodegradable; memiliki kadar toksisitas rendah; biocompatible dan digestible; dapat diperoleh dari bahan-bahan murah; dan ekonomis. (Emeritus, 2001).

Berdasarkan penelitian yang dilakukan oleh Silva et al. (2014) biosurfaktan terbukti efektif untuk bioremediasi lingkungan terkontaminasi minyak. Jenis biosurfaktan seperti : glucolipid, rhamnolipid, lipopeptide, dan trehalose emenjadi biosurfaktan utama dalam proses bioremediasi oil spill. Biosurfaktan tersebut dapat diproduksi dari beberapa mikrobia yang bersifat patogen, sehingga beberapa bersifat toksis dalam dosis tertentu.

Dalam kasus ini dilakukan pengujian penambahan biosurfaktan kepada tanah tercemar (oil spill) dari Cepu. Parameter yang difokuskan pada penambahan biosurfaktan tersebut yaitu TPH, pH, BTex, dan logam berat. Biosurfaktan juga cukup efektif dalam menurunkan IFT minyak mentah (crude oil) dan air formasi serta dapat menurunkan viskositas minyak dan menyisihkan air dari minyak.

Biosurfaktan adalah zat permukaan aktif yang disintesis oleh sel hidup dan memiliki sifat-sifat mengurangi tegangan permukaan, menstabilkan emulsi, pembentukan busa, pada umumnya tidak beracun dan biodegradable (Banat et al, 2000). Biosurfaktan merupakan surfaktan yang disintesis oleh mikroorganisme, terutama jika mereka ditumbuhkan pada substrat yang tidak larut dalam air. Tidak seperti surfaktan berbahan dasar minyak yang diklasifikasikan berdasarkan grup polar natural-nya, biosurfaktan dikategorikan berdasarkan struktur kimia dan bakteri penghasilnya. Pada umumnya, struktur kimiawi biosurfaktan terdiri atas gugus hidrofilik yang mengandung asam amino atau anion dan kation peptida, mono-, di-, atau polisakarida; dan gugus hidrofobik yang mengandung asam lemak jenuh dan tak jenuh.

Berdasarkan ukuran molekularnya, biosurfaktan dapat dibagi menjadi biosurfaktan dengan berat molekul rendah dan berat molekul tinggi. Glikolipid seperti rhamnosa dan sophorolipid, dan lipopeptida seperti surfactin dan polymyxin merupakan biosurfaktan dengan berat molekul rendah, yang berfungsi menurunkan tegangan permukaan dan tegangan antar permukaan. Sedangkan biosurfaktan dengan berat molekul tinggi seperti lipoprotein, lipopolisakarida, dan amphipatik polisakarida sangat efektif untuk menstabilkan emulsi minyak dalam air. Berdasarkan struktur kimianya, biosurfaktan diklasifikasikan sebagai glikolipid; lipopeptida atau lipoprotein; asam lemak, fosfolipid, biosurfaktan polimerik; dan biosurfaktan partikulat.

\section{METODOLOGI}

Metode yang digunakan adalah pengolahan tanah secara $e x$-situ, yaitu tanah yang akan diolah dipindahkan dari tempat asalnya dan dilakukan treatment pada tempat lain. Tanah yang digunakan diambil dari sekitar sumur kw-55 dan kw-58. Tempat pengolahan tanah tersebut berupa bak penampungan berdimensi $2 \mathrm{~m} \times 1 \mathrm{~m} \times 0,5 \mathrm{~m}$ dengan permukaan yang impermeabel yang dapat dilihat pada Gambar 1. Langkah-langkah dalam percobaan ini sebagai berikut :

Tanah tercemar yang sudah dikumpulkan dimasukkan dalam bak pengujian dengan dimensi $2 \mathrm{~m} \times 1 \mathrm{~m}$ x $0,5 \mathrm{~m}\left(1 \mathrm{~m}^{3}\right)$.

a. Tanah tersebut digemburkan dengan cara diaduk terus-menerus menggunakan sekop hingga menjadi homogen atau merata.

b. Sambil digemburkan sampel tanah diberikan air sebanyak $150 \mathrm{~L}$ untuk melembabkan tanah sambil diaduk selama 30 menit.

c. Dilakukan penambahan larutan biosurfaktan "U-Champ" sebanyak $16 \mathrm{~L}$ dengan pelarut air sebanyak $90 \mathrm{~L}$ sebagai pengolahan secara bioremediasi tanah sambil terus diaduk. Proses berlangsung selama 2-4 jam.

d. Dilakukan leaching atau pencucian sampel tanah dengan cara menambahkan $150 \mathrm{~L}$ air bersih dan didiamkan selama 2 jam.

Tanah yang tercemar memiliki tekstur geluh lempungan setelah diteliti. Tekstur tersebut menandakan bahwa tanah tersebut memiliki permeabilitas yang terbilang rendah dikarenakan ukuran butir lempungnya. Hal tersebut akan 
membuat infiltrasi pada tanah menjadi kecil dan menyebabkan jumlah minyak dalam tanah tidak terlalu dalam. Total penambahan larutan pada $1 \mathrm{~m}^{3}$ (1000 L) sampel tanah yaitu $390 \mathrm{~L}$ dengan penambahan biosurfaktan "UChamp" sebanyak 16 L. Proses pencampuran larutan dan tanah berlangsung selama kurang lebih 6 jam.

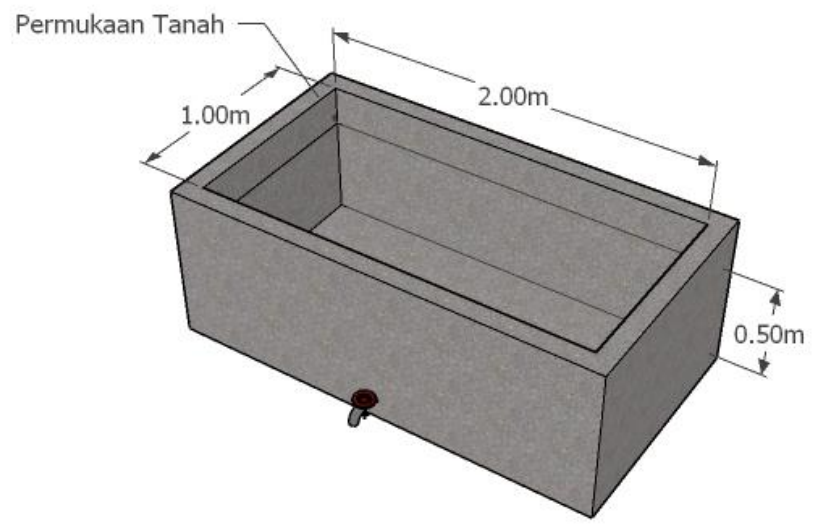

Gambar 1. Ilustrasi bak pengolahan tanah

\section{HASIL DAN DISKUSI}

Kecamatan Cepu yang terletak di Kabupaten Blora, Jawa Tengah merupakan salah satu tambang minyak bumi secara konvensional yang masih aktif mengeksploitasi minyak bumi dalam jumlah besar. Daerah dengan sebutan Teksasnya Bojonegoro ini telah memroduksi migas sejak tahun 1893 hingga sekarang. Proses produksi yang dilakukan pada daerah ini mulai dari drilling hingga refining yang dilakukan dengan cara yang sangat sederhana.

Selama proses produksinya tambang migas ini menyisakan tumpahan minyak mentah yang jumlahnya sangat besar dan membahayakan lingkungan bila tidak ditangani dengan baik. Komponen hidrokarbon yang tercecer tersebut bersifat toksik dan dapat berpengaruh pada kesuburan tanah yang terpapar. Hal tersebut dapat menyebabkan berkurangnya unsur hara tanah dan tanah tersebut menjadi tandus. Oleh karena itu perlu dilakukan remediasi bagi tanah tercemar crude oil untuk menjaga kualitas lingkungan. Kenyataanya, di lapangan limbah tersebut bahkan tidak diperhatikan sehingga lingkungan pada lokasi tambang migas tersebut sangat rusak, baik tanah di sekitarnya maupun perairannya.

Oleh karena itu, mengacu kepada Kepmen LH No 128 tahun 2003 tentang Tata Cara dan Persyaratan Teknis Pengolahan Limbah Minyak Bumi dan Tanah Terkontaminasi oleh Minyak Bumi Secara Biologis, limbah oil spill tersebut harus diolah, salah satunya dengan pengolahan secara biologis (bioremediasi).

Pada penelitian ini tanah yang tercemar memiliki konsentrasi TPH sebesar 13,49\% sehingga tanah tersebut tidak perlu diolah terlebih dahulu untuk dilakukan bioremediasi. Penambahan biosurfaktan "U-Champ" sebagai prapengolahan oil spill bertujuan untuk menurunkan konsentrasi TPH dan BTex.

\subsection{Kondisi Awal}

Pada kondisi awal diperoleh beberapa nilai dari parameter TPH, $\mathrm{pH}$, dan logam berat (heavy metal). Sianipar dan Kardena (2011) menyatakan bahwa syarat optimal untuk pengolahan secara bioremediasi yaitu pH pada rentang 6 9 dan TPH di bawah 15\%. Kedua syarat tersebut terpenuhi pada sampel tanah, dimana nilai pH sebesar 9,21 dan kadar TPH sebesar 13,49\%. Dengan demikian kondisi awal pada sampel tanah tidak menjadi masalah dalam penggunaan biosurfaktan untuk proses bioremediasi. Terdapat beberapa logam berat pada sampel tanah yang dapat bersifat toksik pada organisme tanah, diantaranya $\mathrm{Pb}, \mathrm{Ba}, \mathrm{Cr}, \mathrm{Cu}, \mathrm{Hg}$, $\mathrm{Se}$, dan $\mathrm{Zn}$.

\subsection{Kondisi Akhir}

Berdasarkan pengujian, diperoleh penurunan nilai TPH dan $\mathrm{pH}$, sedangkan untuk kadar logam berat mengalami beberapa penurunan dan peningkatan. Perbandingan konsentrasi sebelum pengolahan dan setelah pengolahan dapat dilihat pada Tabel 1. 
Tabel 1. Perbandingan parameter sebelum dilakukan pengujian dan setelah dilakukan pengujian dengan biosurfaktan "U-Champ"

\begin{tabular}{lll}
\hline Parameter & Sebelum & Sesudah \\
$\mathrm{TPH}$ & $13.49 \%$ & $9.39 \%$ \\
$\mathrm{pH}$ & 9.21 & 7.16 \\
$\mathrm{~Pb}$ & $63.2 \mathrm{ppm}$ & $60.6 \mathrm{ppm}$ \\
$\mathrm{As}$ & $0 \mathrm{ppm}$ & $0 \mathrm{ppm}$ \\
$\mathrm{Ba}$ & $249.6 \mathrm{ppm}$ & $302.9 \mathrm{ppm}$ \\
$\mathrm{Cd}$ & $0 \mathrm{ppm}$ & $0 \mathrm{ppm}$ \\
$\mathrm{Cr}$ & $89.5 \mathrm{ppm}$ & $91.4 \mathrm{ppm}$ \\
$\mathrm{Cu}$ & $63.4 \mathrm{ppm}$ & $64.6 \mathrm{ppm}$ \\
$\mathrm{Hg}$ & $24.6 \mathrm{ppm}$ & $10.9 \mathrm{ppm}$ \\
$\mathrm{Se}$ & $1.5 \mathrm{ppm}$ & $2.6 \mathrm{ppm}$ \\
$\mathrm{Zn}$ & $1260 \mathrm{ppm}$ & $1030 \mathrm{ppm}$ \\
\hline
\end{tabular}

Dengan penambahan larutan Biosurfaktan "U-Champ" didapatkan penurunan TPH dari 13,49\% menjadi 9,39\%. Terjadinya penurunan TPH ini menunjukkan keefektifan biosurfaktan dalam penurunan TPH. Meski demikian, kandungan TPH dalam tanah masih tergolong buruk, dikarenakan kandungan TPH masih jauh di atas baku mutu, yaitu Kepmen LH No 128 tahun 2003 tentang Tata Cara dan Persyaratan Teknis Pengolahan Limbah Minyak Bumi dan Tanah Terkontaminasi oleh Minyak Bumi Secara Biologis. Penurunan TPH dapat dilihat pada Gambar 2.

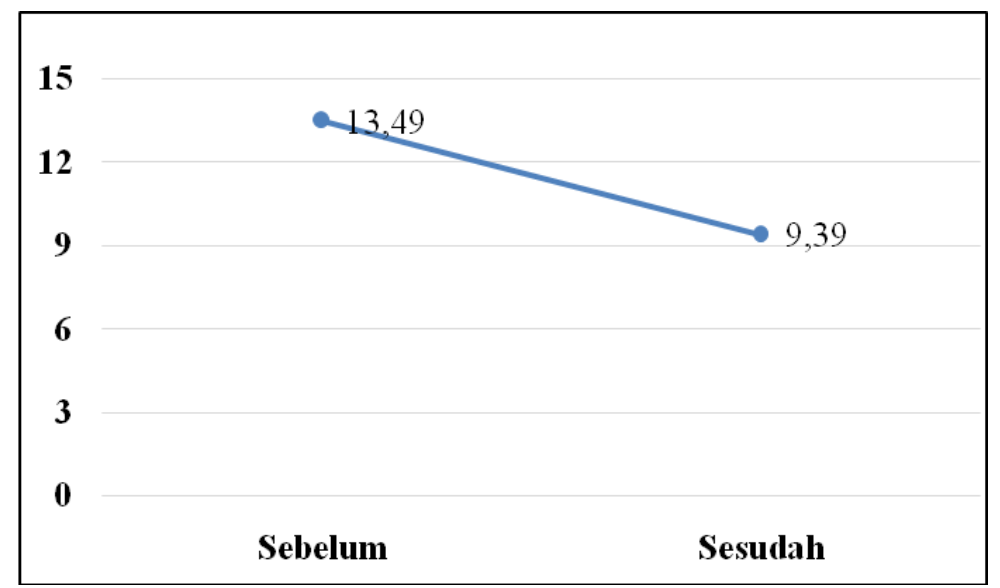

Gambar 2. Grafik penurunan kadar TPH pada tanah setelah dilakukan pengolahan (satuan \%)

Penurunan $\mathrm{pH}$ menurut hasil pengujian yaitu dari 9,21 menjadi 7,16. hasil tersebut menunjukkan bahwa metode ini efektif untuk menetralkan situasi basa menjadi netral. Dalam kondisi netral ini mikrobia akan lebih mudah berkembangbiak dan bekerja untuk memecah hidrokarbon pada tanah tercemar. Grafik penurunan tingkat keasaman tanah dapat dilihat pada Gambar 3. 


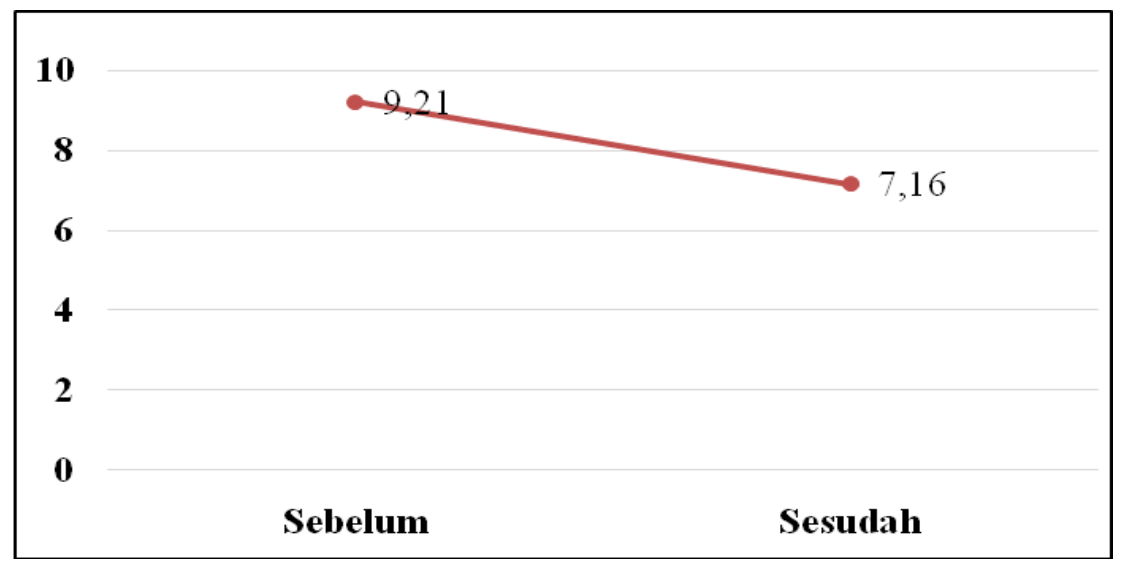

Gambar 3. Grafik penurunan kadar pH pada tanah setelah dilakukan pengolahan

Hasil analisa logam berat dapat dilihat pada Gambar 4 diperoleh beberapa penurunan dan peningkatan unsur logam berat. Penurunan logam berat tersebut menandakan keefektifan biosurfaktan dalam menguraikan logam berat, namun beberapa logam berat terlihat meningkat kadarnya. Hal tersebut diduga karena air yang digunakan untuk proses pengolahan mengandung beberapa logam berat. Tingginya beberapa unsur logam berat ini akan bersifat toksik untuk mikrobia, sehingga perlu dilakukannya pengolahan lebih lanjut untuk proses bioremediasi.

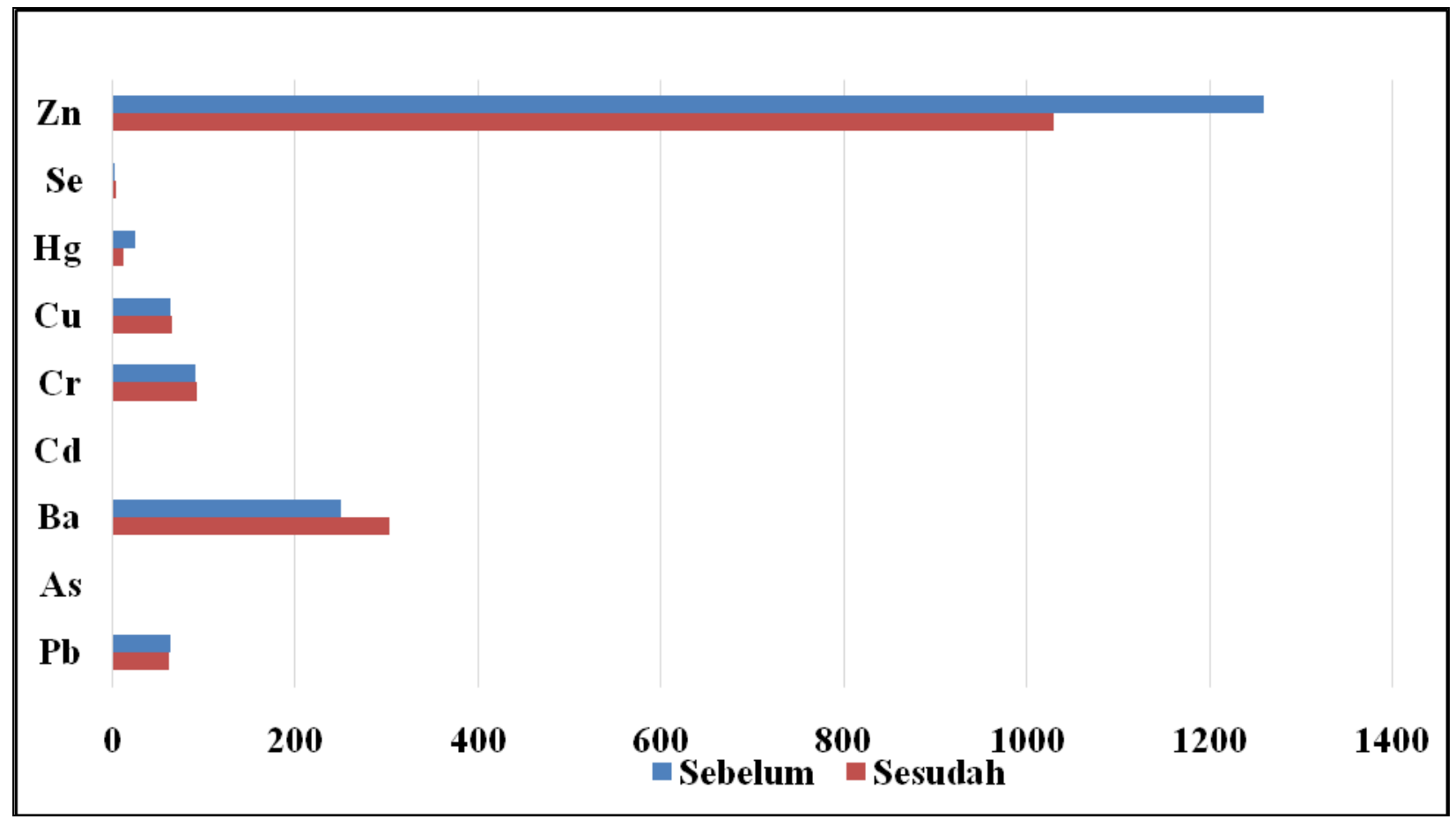

Gambar 4. Perbandingan kandungan logam berat pada tanah sebelum pengolahan dan sesudah pengolahan (satuan ppm)

Harry Budiharjo S., Joko Pamungkas, Sri Rahayu G, Kevin Yudha Perwira 


\section{KESIMPULAN DAN SARAN}

Penggunaan biosurfaktan "U-Champ" dalam pengolahan oil spill cukup efektif dalam menurunkan TPH dan menetralkan $\mathrm{pH}$. Meskipun TPH yang diturunkan masih belum memenuhi baku mutu lingkungan sesuai Kepmen LH No 128 tahun 2003 tentang Tata Cara dan Persyaratan Teknis Pengolahan Limbah Minyak Bumi dan Tanah Terkontaminasi oleh Minyak Bumi Secara Biologis, namun tingkat keasaman (pH) dapat diturunkan menjadi netral. Kadar logam berat yang tinggi belum berhasil diturunkan menjadi kadar aman bagi lingkungan. Beberapa parameter seperti $\mathrm{Ba}, \mathrm{Cr}, \mathrm{Cu}$, dan $\mathrm{Se}$ justru mengalami peningkatan setelah dilakukan pengolahan.

Sebaiknya dilakukan beberapa pengujian ulang dengan penambahan variabel kontrol. Penelitian ini tidak memperhatikan tekstur tanah dan kadar toksisitas $\left(\mathrm{LC}_{50}\right)$ dari biosurfaktan tersebut sehingga penelitian ini belum membahas mengenai faktor ekologis daerah penelitian. Apabila dilakukan penelitian lebih lanjut, sebaiknya memperhatikan faktor fisik tanah dengan cara menambah variable tanah tercemar dengan karakteristik tanah yang berbeda sehingga dapat dilakukan pengolahan yang sesuai dengan tekstur tanah daerah penelitian tersebut. Perlu juga dilakukan penambahan variable penguji dengan konsentrasi yang berbeda untuk mendapatkan nilai efisiensi dan ekonomis dari biosurfaktan tersebut.

\section{DAFTAR PUSTAKA}

Banat IM, Makkar RS, Cameotra SS. (2000). Potential commercial applications of microbial surfactants. Appl Microbiol Biotechnol. 53(5): 495-508.

Emeritus. (2001). Biosurfactant and their application for soil bioremediation. N.KOSARIC. Vol 39 No 4 (295-304)

Hidayat, Syarif. (2009). Pengaruh variasi suhu dan pengadukan terhadap produksi biosurfaktan oleh Azotobacter vinelandii dalam fermenter 10 liter. Bandung : Laporan Tugas Akhir Departemen Teknik Lingkungan.

Kusumawati, Eko; Wignyanto; dan Kholiq, M.Abdul. (2012). Aplikasi bakteri untuk bioremediasi lahan tercemar minyak bumi (crude oil) menggunakan teknik biopile. Polhasains. Vol 3 No 1 (1-11).

Nuryana, Dwi. (2017). Review : bioremediasi pencemaran minyak bumi. Journal of Earth Energy Engineering. Vol 6 No 2 (9-13)

Rocha e Silva, N.M.P; Almeida, D.G.; Rufino, R.D.; Luna, J.M.; Santos, V.A.; Sarubbo, LA. (2014). Applications of biosurfactants in the petroleum industry and the remediation of oil spills. International Journal of Molecular Sciences.

Sianipar, Merry dan Kardena, Edwan. (2011). Pengaruh penambahan biosurfaktan sebagai prapengolahan Lumpur dalam menurunkan TPH melalui oil recovery pada teknik bioremediasi fase slurry. Jurnal Teknik Lingkungan. Vol 7 No 1 (23-34) 